\title{
A QUALITATIVE ANALYSIS OF SOCIOLOGICAL FACTORS AFFECTING SUGARCANE PRODUCTIVITY IN CENTRAL VALLEY OF KHYBER PAKHTUNKHWA, PAKISTAN
}

\author{
Muhammad Nisar $^{1 *}$, Asad Ullah ${ }^{2}$, Fazal Hanan ${ }^{3}$, Younas Khan ${ }^{4}$, Habib Ur Rahman ${ }^{5}$ \\ ${ }^{1 *}$ Lecturer in Sociology, Department of Sociology and Political Sciences, Bacha Khan University Charsadda, Pakistan; \\ ${ }^{2}$ Assistant Professor, Department of Rural Sociology, The University of Agriculture, Peshawar, Pakistan; ${ }^{3}$ Assistant \\ Professor, Department of Sociology, FATA University TSD Darra, NMD Kohat KP, Pakistan; ${ }^{4}$ Lecturer in Sociology, \\ Department of Sociology and Political Sciences, Bacha Khan University Charsadda, Pakistan; ${ }^{5}$ Ph.D., Scholar, \\ Department of Rural Sociology, The University of Agriculture, Peshawar, Pakistan. \\ Email: ${ }^{1 *}$ muhdnisar@bkuc.edu.pk, ${ }^{2}$ asadpsh@aup.edu.pk, ${ }^{3}$ dr.hanan@fu.edu.pk, ${ }^{4}$ youniskhan@bkuc.edu.pk, \\ 5habibhay@gmail.com
}

Article History: Received on $31^{\text {st }}$ May 2021, Revised on $15^{\text {th }}$ June 2021, Published on $15^{\text {th }}$ June 2021

\begin{abstract}
Purpose of the study: This research study was designed to analyze various social factors like population dynamics, institutional, land tenure, and gender other than the technological one that affects the production of sugarcane in farming communities.
\end{abstract}

Methodology: The method of the study was qualitative, where the data was collected through FGDs. Two FGDs were conducted in two districts of the central valley of Khyber Pakhtunkhwa-Pakistan. Each FGD consisted of 10 participants. The data was analyzed through thematic analysis.

Main Findings: The findings of the study revealed that sugarcane productivity is affected by sociological factors like technological ones. The poor socioeconomic status of the farmers, wasting resources in land disputes, frequent land division among heirs, a rapid increase of population growth, unplanned urbanization conversion of fertile agricultural land into the built environment, weakening the role of informal institutions like Jirga and farmers organizations, lack of access to agricultural institutions, the restricted role of women in farming and unfavourable attitude of farmers towards new agrarian technologies, all were the significant contributing factors that negatively influenced sugarcane productivity.

Applications of this study: The findings of the study be used by the agricultural department, NGOs, and the government while taking into consideration the factors responsible for sugarcane productivity.

Novelty/Originality of this study: This study is novel that no study has yet conducted while considering sociological factors in sugarcane production in Pakistan. This research a unique in that provides a base for agricultural scientists to keep in mind social factors as well in agrarian production besides technological factors.

Keywords: Sugarcane, Productivity, Land Disputes, Fragmentation, Urbanization, Population Growth, Women Role, Model Farm Services Centers.

\section{INTRODUCTION}

Sugarcane crop production is a complex process and mostly rely on different arrangement and application of various factors like land, finance, management practices, and labour, etc. Such kinds of variation in use influence crop production (Ali et al., 2013). Pakistan is on $9^{\text {th }}$ in raking in white sugar production and export (PSMA, 2017). Furthermore, it $5^{\text {th }}$ the case of sugarcane production and area while $52^{\text {nd }}$ in its per acre yield $(\mathrm{FAO}, 2016)$, but unfortunately the sugar recovery rate is just 9 to 10 percent in comparison to the advanced nations (Zaidi et al., 2013).

In Pakistan, sugarcane contributes 3.6 percent to the agriculture sector and 0.7 percent in value addition in Gross Domestic Product (GOP, 2018). It is the prime cash crop .and after textile s, it is the second agro-based industry in Pakistan. About 1.5 million people are involved in labour in the sugarcane industry. It is usually grown for 'guru' and sugar production in Pakistan. Its by-products are also utilized for particles boards preparation, in-house power generation, paper formation (Khan and Deshmukh, 2015), and as feed for animals during winter when rabi fodder shrink (Sharif et al., 1994).

In 2017-18 the government of Pakistan wanted to maintain the demand for the sugar for domestic and export purposes, the sugarcane grown size was increased to $7.8 \%$ and was cultivated on an area of 1.3 million hectares (GoP, 2018). A provincial-wise comparison shows that Punjab is on the top in the area and production of sugarcane, followed by Sindh and Khyber Pakhtunkhwa (as depicted in Table 1). Furthermore, the per acre yield of cane in Khyber Pakhtunkhwa is also low as compared to Sindh and Punjab provinces. In Khyber Pakhtunkhwa, sugarcane is cultivated in 17 districts on an area of 0.1116 million hectares, which is contributed of $8.55 \%$ to the total country production. Among these districts, Charsadda is the leading one in terms of size followed by Mardan, D.I Khan, Peshawar, Nowshera, Malakand, and Swabi (GoKP, 2018). 
Table 1: Sugarcane Area and Production by Province

\begin{tabular}{lllllll}
\hline \multirow{2}{*}{ Province } & \multicolumn{2}{l}{ Area ('000' Hectares) } & \multicolumn{4}{c}{ Production ('000' Tons) } \\
\cline { 2 - 7 } & MY 2016/17 & MY 2017/18 & MY 2018/19 & MY 2016/17 & MY 2017/18 & MY 2018/19 \\
\hline Punjab & 782 & 864 & 790 & 49,700 & 56,000 & 47,300 \\
\hline Sindh & 320 & 333 & 300 & 20,200 & 20,300 & 19,000 \\
\hline Khyber Pakhtunkhwa & 118 & 118 & 110 & 5,600 & 5,700 & 5,200 \\
\hline Baluchistan & - & - & - & - & - & - \\
\hline Total & 1,220 & 1,315 & 1,200 & 75,500 & 82,000 & 71,500 \\
\hline
\end{tabular}

Sources: MNFSR, PSMA, and FAS/Islamabad (MY represents Marketing Year)

The actual and potential gap that exists between sugarcane productivity in Pakistan is due to some technical and socioeconomic reasons (Nazir et al., 2013) as well as other constraints like irregular and low fertilizers application, high weed infestation, intercropping, and insect and pest management that are affecting the production of sugarcane (Ahmad et al., 2012).

Keeping the importance of sugarcane, the establishment of Sugar Crops Research the Institute (SCRI) established in 1952, which was then given the status of the institute in 1981, in which sugar beet was also included for research purposes. The domain of SCRI consists of the research on sugar beet and sugarcane. Its focus is on the development of different varieties of sugar beet and sugarcane, which are more disease resistant, high quality, and high output yield. Important cultivated varieties of sugarcane in the central valley of Khyber Pakhtunkhwa are Mardan-93, CP 77-400, SPSG 394, Mardan 2005, CP 80-1827, CP 85-1491 and CP 91-582 (https://www.scri.gkp.pk/index.html accessed on $\underline{02 / 12 / 2019)}$.

\section{JUSTIFICATION OF THE STUDY}

Sugarcane is an important cash crop of the Khyber Pakhtunkhwa province; however, its production comparably to other regions is relatively low. The area is facing high population growth rates. As a result, there is tremendous pressure on the agricultural sector to meet the growing food and other related production needs of the population. The situation is further aggravated by high encroachment on agricultural lands for the construction of urban settlements. Agriculture and its allied departments are striving hard to overcome the problem of low sugarcane productivity by providing agriculturally based technological innovations to the farmers. However, the sector is far from achieving its targets. There are evidence of uneven distribution of these technical benefits without taking into consideration the socio-economic, institutional, and cultural requirements of the farming communities. As a result, the technologies are neither properly diffused nor implemented in their true spirit to uplift sugarcane productivity.

\section{Objective of the study}

This research study, therefore, is designed to analyze various population dynamics, institutional, tenure related factors, and communicational aspects that affect the production of sugarcane in farming communities.

\section{REVIEW OF LITERATURE}

The literature reveals that for farmers who experienced land-related disputes, the crop productivity of these farmers is decreased by almost 13 percent, while fear of disputes in the future decreases the agricultural productivity by 9 percent (Muyanga \& Gitau, 2013; Eklund et al., 2015). Similarly, Muawanah (2018) revealed that in Cambodia, farmers lost total access to their parcels because of land disputes that retard the socio-economic development of the area as well.

It has been found that due to the hereditary laws land is divided among several heirs, due to which individually owned agricultural land is continuously decreasing in size. Farmers cannot use high-quality inputs due to their higher costs in a small pieces of agricultural lands which leads to the reduction of agricultural productivity (Mughal, 2019; Okezie, et al., 2012). Recently, numerous countries have undertaken land reforms to promote farms integration (Khan et al., 2012). Iheke (2009) noticed that there is a positive association between large farm size and agricultural productivity. This could be the result of the use of modern machinery and technology, which is only possible to use on the large open farm. Similar other studies the relationship of the size of land and the rate of adoption of modern agricultural technology (Kasenge, 1998; Gabre-Madhin \& Haggblade, 2001; Uaiene et al., 2009; Mignouna et al, 2011).

Commercial use of land, such as for shops, houses, industries, etc. Are regularly happening, which asymmetrically expanding their boundaries over many agricultural land parcels. With a growing population, the landholding and farm fragmentation is multiplying day-by-day that affects agricultural activities negatively (Samiullah, 2018). Population growth in the cities means the increasing demand for urban land, especially for houses, and other purposes as well like industrial, residential, and infrastructure development. Such land conversion mostly reduces the fertile agricultural land, which resultantly, affects agricultural productivity and food security (Francis et al., 2013; Samiullah, 2018).

The literature on the influence of urbanization on the conversion of agricultural land found different opinions. Some studies found just a marginal effect of urbanization on agricultural land while others stated that urbanization has devastating effects on agricultural land and agricultural productivity as stated by (Deng et al., 2015; Malik \& Ali, 2015). 
In some countries like China, China's Cultivated Land Balance (CLB) programs launched to protect the agriculture from the effects of urbanization that has devastating effects on agricultural productivity (WB \& DRC, 2014; Song \& Pijanowski, 2014).

Farmer's participation is necessary to get community support for agricultural development programs (Cole, 2007) as without participation; no partnership, no program, and no developments (Aref et al., 2010). It is found that farmers in through informal institutions share information about quality inputs and devised strategies to counter the problems of counterfeits in the market. It is also observed that there is a significant positive association between the level of intercaste collaboration and the agricultural productivity of the farmers (BenYishay \& Mobarak, 2013; Ashour et al., 2016).

Farmers' access to Model Farm Services Centers (MFSCs) revealed that the average yield of crops increases after registration and getting training from MFSCs by farmers (Ullah et al., 2010). Nowadays numerous Model Farm Institutions are involved in different crops value chains like sugarcane, malt barely, etc. (BIF, 2018; Tefera et al., 2016). Some of these approaches follow microcredits plus approaches, as suggested by Bastiaensen \& Marchetti (2011), their role goes beyond financial support. They deliver inputs in kind, facilitate market linkages and provide agricultural training which influences agricultural productivity positively (Tefera et al., 2016).

Women represent almost half of the world's population as well as provide 60 to 80 percent of agricultural labor, yet less than 5 percent of them possess the land. Secure land rights provide women with greater incentives to adopt modern sustainable farming methods and invest in land, to increase productivity and make a contribution to household food security. Property rights of women increase their status and bargaining power in the household and community (RDI, 2007). Butt et al. (2010) found in their study in Pakistan the women in rural areas active in the agriculture, cottage, and livestock sector but they are lacking access to agricultural credit and good markets on one hand, while a high level of education and skill are also absent on the other hand. Access to good credit services may be channelled through dedicated programmes. Pakistan Bureau of Statistics (2008) showed that in Pakistan male applicants are dominant borrowers (87\%) over female. This disparity can be observed both in the number and amount of loan provided to women. Agricultural entrepreneurship activities should be enhanced among women folk along with the provision of short-term insurance against any weather-related shocks. Furthermore, women cooperatives are to be encouraged which are rarely found (

Studies found that farmers should have the least knowledge of new agricultural technologies, new crops, new cultivation methods, water management, pesticides, seeds, and marketing of the products to compete in the global market (Singh et al., 2011; Saadi et al., 2008). To achieve this, farmers should adopt improved and locally acceptable agricultural technologies (Hassan, 2000). Perviaz et al. (2013) analyzed the use of new technologies in sugarcane crops in Pakistan. They found that most of the farmers were illiterate, poor, and were using traditional farming of sugarcane cultivation. The study further found that the role of extension workers in the diffusion and adoption of new technologies was negligible (Ahmad et al., 2012). Habib et al. (2014) found that for those growers who can take the risk of using new inputs like quality seeds, chemical fertilizers, etc. their sugarcane productivity was higher than their counterparts. Reza (2016) stated that outdated and old production machineries and techniques, low quality of sugarcane seeds, and inefficient manpower are the major factors behind low productivity and low profitability among Bangladeshi sugarcane growers than Indian, Brazil, or Pakistan.

\section{MATERIAL AND METHODS}

\section{Study area}

The current research study was conducted in the Central Valley of Khyber Pakhtunkhwa, where the sugarcane is grown as a cash crop as most the farmers are relying on this crop.

\section{Tool of data collection}

Focus group discussion has been used as a method/tool of data collection. FGD is a method of gathering qualitative information regarding a topic through informal group discussions (Leech \& Onwuegbuzie, 2007, 2008). It gives an interactive discussion through which the participants openly discuss an issue and reason the arguments to provide an indepth description of different angles of a case under study. In this way, some deep and common responses are obtained that help to explain the problem or issue in a logical sequence (Glaser, 1978, 1992; Strauss, 1987; Charmaz, 2006).

Two separate Focus Group Discussions (FGDs) were conducted, each in Union Council Hathian of District Mardan and Union Council Prang of District Charsadda. The FGDs were arranged with the help of local farmers and the agriculture department. Each FGD were participated by 10 members. The participants included progressive farmers that acted as opinion leaders in the community, employees of MFSCs (Field Assistant), agricultural input (fertilizers and pesticides) dealers, and NGO representatives that were directly or indirectly attached with the agriculture sector. The discussion of the FGDs was focused on various technical and social factors that directly or indirectly affected sugarcane productivity. The technological aspects included various field operations in sugarcane farming, diversity in inputs, output, and net sugarcane production. Moreover, the focus of social factors the influence sugarcane production was limited to the role of socioeconomic status (SES) of the farmers, access to Model Farm Services Centers, the influence of urbanization and 
population growth, role of informal institutions, land fragmentation, land disputes, and attitude toward agricultural innovations.

\section{Procedure of FGDs}

Two FGDs with farmers were conducted in the Central Valley of Khyber Pakhtunkhwa (one each in District Mardan and District Charsadda) in 2020-2021. The theme of these FGDs was sugarcane productivity and our objective was to explore either social factors influence the sugarcane productivity of farmers or not.

\section{Interview protocol and logistics}

The researcher conducted FGDs with the help of an assistant moderator by watching videotapes and guidance from skilled and experienced FGD researchers, and pilot testing.

FGDs were held in Hujras (the gathering place of Pashtuns) in each District, where ten members have participated in each discussion. Each FGD session was about 2 hours long. The aim of the study was explained to the participants and assurance was given to keep their information secret.

The discussions were recorded as well as notes were taken by the assistant moderator with the permission of the participants. After the end of each session, the researchers reviewed the notes and provided the necessary clarification by the assistant moderator.

\section{Data analysis}

The data of each FGD was compiled in a two-step process. Firstly, the audiotapes and were listened to and made an abridged transcript of each session. Secondly, a bulleted summary for each question was prepared in each session to abridge transcripts. The bulleted summaries were then coded by the researcher to establish reliability.

\section{Analysis of focus group discussion data (FGD)}

FGDs data was analyzed through the content analysis method (Morgan, 1988). For this purpose, the information was coded into several codes based on similarity and variances of responses (Charmaz, 2006). These codes were also helpful in the determination of frequencies of different ideas as reported by the key informants of FGDs and to draw relationships among different emerging ideas with each other. Thus, the content analysis helped in describing numerous study themes in an interactive manner (Morgan, 1988), with some detailed interpretative accounts from the everyday social life of the respondents (Carey \& Smith, 1994; Morgan, 1995). Data collected through FGDs was also helpful to second and explained the data collected during a quantitative phase. The analyzed data was consolidated into a coherent descriptive report and written in a narrative format. Findings of the FGDs was shared with the critical informants for its validation to increase its credibility (Angen, 2000; Doyle, 2007; Birt et al., 2016).

\section{Focus group discussion results}

The leading factors that influenced the sugarcane productivity of farmers, as mentioned during the discussion by the participants, are discussed below in detail.

\section{Why cultivate sugarcane?}

The FGD participants were asked the reason for cultivating sugarcane as a preferred crop over others. The participants explained the economic and technical reasons for choosing the sugarcane crop over others. It was informed that, in financial terms, sugarcane is a cash crop with a high yield and productivity compared to other crops grown in the area. As a result, the cash return from the sugarcane crop is much higher than other crops. Furthermore, the crop can be sold both in crude and refined shape through value addition to the crop and its products like "Gur" and sugar. Thirdly, due to in ng population needs for sugar, this crop almost always fetches high financial returns. In case of market fluctuation of sugarcane prices, the farmers have alternate options to convert the crop into a locally produced product named as 'Gur' which, can be stored for a longer time and earn a high income. Moreover, the byproducts of sugarcane are used as fodder to feed the animals or as a source of energy. The 'Gur' produced at the local level factories is the most preferred alternate to sugar and delightfully used by the rural communities to sweeten different food items. On the technical side, it was added by the participants that the sugarcane crop is comparatively low labour and input-intensive. Once cultivated, the crop can be harvested two or more times. In addition, due to high insect/pests and disease resistance, the sugarcane crop requires comparatively low application of pesticides and herbicides, etc., and chemical sprays. The farmers further added that the sugarcane crop could be mix cropped with wheat, barley, tomato, and other vegetables at one time.

\section{Sociological factors contributing to the sugarcane production process}

Like other crops, the growth and production of sugarcane is more a biological process greatly dependent upon climatic and edaphic factors. The technical inputs of agronomists and related research scientists have remained the focal point in determining the sugarcane productivity. However, the farmer and his social settings are of equal significance that directly or indirectly influences sugarcane production, as reported by the participants in the FGDs. These factors are broadly categorized as natural/environmental factors (physical environment, climate, and soil fertility, etc.), direct causes 
(quality inputs, irrigation, etc.), and underlying causes (socioeconomic status, land disputes, land fragmentation, influence of population growth, influence of urbanization, role of informal institutions, women role and attitude towards agricultural innovations). A sequential explanation of various social factors influencing sugarcane productivity, as analyzed from the FGDs results, is as follows.

\section{Socioeconomic status of the farmers and sugarcane productivity}

Socioeconomic status, as reported by the respondents, was described as the most important underlying factor for sugarcane productivity, with monthly family gain, literacy level, and size of landholding as its significant indicators. High income, awareness, and landholding help farmers not only getting sufficient knowledge of quality inputs, technologies, and practices that are necessary for the sugarcane production process but also ensure the actualization of such innovative knowledge in the shape of best practices that are necessary for increased sugarcane yield. The high socioeconomic status also safeguarded the farmers from economic shocks and compelled them to take risks involved in an innovative approach. Ensuring timely availability of agricultural inputs in required quantum by the high socioeconomic status farmers is an additional contributor to enhance sugarcane production.

Some of the key informants added that the high socioeconomic status farmers were advantageous over low socioeconomic status farmers in terms of better management of their agricultural lands and efficiently solved their land disputes in an efficient manner due to their influential and powerful statuses at the community level. Furthermore, the adverse effect of population growth and excessive land fragmentation were relatively high for farmers from the inadequate socioeconomic status group due to high population growth and low family planning practices exercised by them. Thus, a major chunk of agricultural lands owned by farmers from low and middle socioeconomic status were converted into residential buildings or sold away to pursue of alternate employment opportunities.

Furthermore, the extension agents are highly attracted to high socioeconomic status farmers they are considered as appropriate clients to adopt innovative technologies. Therefore, the representation of high socioeconomic status farmers is disproportionately high in farmer executive committees established by Model Farm Services Centers, such farmers are the prime beneficiaries of subsidized quality inputs, extension agent's visits, and advice regarding agricultural improvement.

It was added that the low socioeconomic status farmers avoided the adoption of expensive and complex agricultural innovations due to the high economic risk to which they were exposed. As a result, the common socioeconomic status farmers are more inclined to subsistent farming rather than commercial farming. These farmers are stuck into a vicious circle of poverty, and are under the debt of dealers, banks, and large farmers and being exploited by them for years and years. Thus, the low socioeconomic status trapped these farmers in the spiral of disadvantage due to economic, awareness, attitudinal, and negligence reasons, resulting in their low agricultural productivity.

\section{Land disputes and sugarcane productivity}

Land ownership, land inheritance, boundaries, and agricultural production share were the primary sources of disputes in the study area. Due to complex and incomplete revenue records, the land ownership and boundary disputes were overwhelmingly high in the study area and were exceptionally derogatory for low socioeconomic status farmers. Moreover, the cultural intricacies in depriving the weak societal segments (women and poor) of their inheritance rights added to the gravity and extent of land disputes. Furthermore, fraudulent sale and purchase of disputed lands or the land with unclear/communal ownership added to the land disputes.

The extent of land disputes ranges from mild disagreement to extreme enmities and legal suits. Most of these disputed lands were not wholeheartedly cultivated by the farmers, especially those from low socioeconomic status groups, as these farmers considered an investment in disputed lands as a risk of loss to such investment. As a result, the disputed lands are poorly managed, insufficiently rehabilitated, low invested, and in some extreme cases, left barren and resulted into its low agricultural production. On the other side, the hostile opponents deploy all measures to stop the rivals from utalizing of land by cutting the irrigation channels or destroying the ripen crops, and damage the contesting farmers. The meager produce of disputed agricultural fields is difficult to transport and sell in appropriate markets due to rivalry among parties. The arguments ridden and demoralized farmers are rarely interested in consulting Model Farm Services Centers or its memberships. Selling disputed land is an easy way to bury the disputes and start any alternate profession. The participants of FGDs, thus, consensually declared land disputes as a significant underlying factor that reduced sugarcane production in the study area.

\section{How to land fragmentation influence sugarcane productivity}

Land fragmentation is another underlying factor of low sugarcane production that is initiated due to rapid population growth. The inappropriate population policies, low awareness, and cultural practices are the multipliers to negatively influence agricultural production due to land fragmentation. Conventionally, the land is inherited among heirs in such a way that each heir receives a fragment of land from each parcel that is inherited by their forefathers. As a result, small, widely dispersed pieces of land are distributed among the heirs without taking into consideration the economic infeasibility of such fragmented land parcels. The construction of an independent house is the utmost priority of each heir; thus, a significant proportion of inherited land is converted into a built environment. The remaining arable land is 
challenging to manage and look after as these fragments are geographically dispersed into small parcels. Furthermore, these miniature farms are not feasible for intensive management, high-quality inputs, and deployment of machinery. In addition, a significant proportion of time is wasted in travelling between these fragments for management and supervision purposes. It was further disclosed during discussions that due to brutal nature, time-consuming, and low returns from fragmented land, the farmers preferred to sell these lands for commercial or residential purposes and get engaged in alternate employments or migrate.

It was also pointed out that land and boundary disputes are standard features of fragmented lands due to the increased numbers of claimants and neighbours. Representatives of low socioeconomic status farmers in FGD pointed out that a significant portion of their fragmented lands was converted into agricultural infrastructures like access paths or irrigation channels as they had to remain independent of their neighbours. It was further added that the government has failed to reintegrate the agricultural land into substantial size fields that are appropriate for farming production. Some of the large and middle socioeconomic farmers, however, are benefited from land fragmentation as these innovative farmers intensively managed the small pieces of agricultural lands in a highly controlled manner to increase their agricultural needs.

\section{Influence of population growth on sugarcane productivity}

During the FGDs, the theme of population growth was described as the mother of multiple, technical, direct, and underlying factors that influenced the agricultural production system. The population growth, according to participants, exerted tremendous pressure on agricultural land as more and more agricultural land is converting to habitation. In addition, the household and industrial wastes produced by the growing population are also dumped in agrarian lands. As a result, it is not only the area of agricultural land, that is squeezing but also degrading its quality. Realistically speaking, the number of family members per farm has increased that increases the numbers of unemployed family members as only a few of their family members are sufficient to manage the small size agricultural fields. In addition, the irrigation water required for farming is also diverted for industrial uses and growing population needs besides choking of irrigation channels due to dumping of household wastes in these channels.

It was further added that the young generation was shy of joining farming as a profession, especially the literate youth. As a result, farming was exercised by aging illiterate farmers who were reluctant to accept innovative agriculture technologies and practices.

Some progressive farmers pointed out that intensification of agriculture to meet the dietary needs of the growing population results in exhaustive use of land and degradation of soil and its denudation from mineral nutrients. Furthermore, the relatively high and immediate returns from the sale of agricultural land or its conversion into housing societies are compelling farmers to make rational choices in favour of selling their agricultural lands.

Some of the progressive farmers, however, have materialized the opportunities and engaged in demand-driven innovative agricultural practices, and act as torchbearers for other farmers. In a nutshell, the population growth is creating a conglomerate of problems that adversely affect agriculture in terms of squeezing land, degradation of land, diversion of the agricultural profession, aging of agriculture profession, and ultimately reducing agrarian production.

\section{Urbanization and sugarcane productivity}

Urbanization was reported as an outshoot of population growth with a profound influence on the population ecology and the social life of the people living in the study area. Urbanization had a multiprong effect on rural-urban migration and expansion of the built environment. The low socioeconomic status farmers tended to migrate to urban areas in search of employment, leading to peripheral growth of nearby cities. In addition, the common living standard of the rural areas was compelling for the wealthy farmers to migrate to such cities with outstanding basic life facilities. As a result, the agriculture profession is dominated by middle socioeconomic farmers. Furthermore, several of the educational and health facilities are initiated by the public and private sectors in rural areas and suburbs due to which population is concentrating around such facilities like commercial markets, industries, health services providing institutions, educational institutions, etc.

The establishment of road networks was pointed out as another important indicator of urbanization. All these spreading infrastructures were highly consumptive of agricultural land. In addition, the waste produced by the urbanized community is an additional source of degradation of agricultural land. Thus, urbanization had a highly negative impact on agrarian production due to its influence on shifting the local population from agricultural profession to other alternates, migration of agricultural labour, conversion of agricultural lands to other land uses degradation of agricultural lands, and competition of urbanized area with the arable lands on water resources, etc.

It was also highlighted that some of the innovative farmers actualized upon the process of urbanization as an opportunity to use modern farming practices like high tunnel farming etc. to grow high-yielding crops like vegetables and fruits to earn a competitive income. 


\section{Role of informal institutions in sugarcane productivity}

The focus group discussions highlighted the importance of social cohesion in the rural community, which provides a foundation for self-help-based activities to achieve agricultural-related goals. These self-help-based activities range from desilting of irrigation channels, construction of community buildings like Hujra (village gathering place), masques (prayer place), construction of access paths in addition to extending help to each other on the occasion of social events like marriages and funerals. These self-help-based activities were institutionalized in highly cohesive societies where the institution of Jirga (council of elders) was established to decide, plan and implement all these self-help-based activities. These jirgas were led by the people of wisdom and traditional authority. Such leaders led the opinion of the community members in the adoption or rejection of agricultural innovation-related technologies.

Moreover, the local agricultural disputes on land ownership, boundaries, agricultural product ownership, and other faction and feuds were resolved by these informal institutions. However, these informal institutions are rapidly eroding in their influence on rural communities due to drastic socioeconomic changes. As a result, the social cohesion among rural communities is weakened with the low interest of the farmers in self-help-based activities. Conversely, the local disputes are seldom presented to jirgas to resolve rather these disputes are contested in courts, which results in wastage of finances and abandoning of fertile agricultural land.

It was further informed that due to some drastic social changes, the informal social institutions are now managed by people from high socioeconomic status and powerful classes instead of people of integrity. As, a result, the rural people have low trust in these institutions as these informal institutions benefit the powerful few at the cost of disfavoring the powerless majority. Furthermore, the child is systematically alienated from these informal institutions, as a result, the youth not only have lost their interest in these institutions but the intellectual memory and wisdom established due to centuries of working of these informal institutions are continuously eroded and lost.

Some of the participants reported the economic constraints and pathologies as significant contributors to degrade the working of informal institutions. In this context, most of the informal institutions were unable to generate and maintain sufficient funds for their utilization on the implementation of self-help-based welfare activities. in addition, the power and money rested in the leadership of informal institutions was corruptly utilized in favour of personal gains or benefiting the nearer and dearer through nepotism and favoritism. The weakening social bonds and the divide between various socioeconomic groups residing in rural areas were giving way to the establishment of some miniature social institutions within the groups of similar socioeconomic status and shared interests to resolve their agricultural-related problems.

\section{How access to Model Farm Services Centers affects sugarcane productivity}

Model Farm Services Centers are the multipurpose formal institutions established to facilitate farmers in technical, social organizational, and inputs related issues under one roof through one window operation. These centers are established at District and Tehsil levels under the administrative set up of Secretary (Agriculture, Livestock, Fisheries \& Cooperatives Departments) and Director-General of Agricultural Extension Department. A Deputy Director (Agricultural Information) works under the Director-General, who further supervised a Deputy Director Coordination and Publication and Support and Technical staff. Agriculture Officer deputed in each district/tehsil works under the direct supervision of Deputy Director Coordination and Publication.

The MFSC works under the principles of integrated and participatory agricultural development approaches. The interested farmers are registered with the MFSCs to whom the available services, in terms of inputs, subsidies, field visits, training, and technical advice are provided.

Most of the farmers that participated in FGDs were not satisfied with the engagement and visits of field assistants to their farms. Therefore, the farmers were constraining to visit MFSCs when they faced any technical problem or to claim the subsidized and innovative inputs or machinery. It was added that the training provided by MFSCs were once in blue moon and primarily to selected blue-eyed. Similarly, the high socioeconomic status, and politically powerful farmers were the prime beneficiaries of subsidized inputs and low rent types of machinery.

The participants representing MFSCs stated that the newly established MFSCs lack financial, technical, and mobilityrelated facilities, the field assistant couldn't visit all farms and provide them the technical advices or inputs.

It was analyzed that farmers who were the members of MFSCs, were the most benefited from the services provided by these centers. These farmers were mostly from high and middle socioeconomic classes with innovative zeal. Hence, they were proactive in approaching the MFSCs or contacting the Field Assistant telephonically to discuss their problems and get timely advice or input support from MFSCs. It was also mentioned that although the field see were not satisfactory from the farmers, yet the farmer's visit to MFSCs has always remained rewarding to the farmers to their satisfaction level. Thus, a unique divide was observed between farmers who visited and those who did not visit MFSCs in terms of their high and low satisfaction from services provided by the MFSCs, respectively. 


\section{Women role in sugarcane productivity}

The discussions on women's role in agricultural presented a subordinate position of women in agricultural-related decisions, activities, and benefits that are typical to a patriarchal culture. The socialization process of girls is distinctly different from boys within the family, with a high emphasis on their obedience and submission. This trait of obedience proliferates all aspects of women's life leading to their deprivation of some of the very basic, legal, religious, and human rights including land ownership and inheritance.

It was judged during discussions that under the spell of highly emphasized obedience during socialization, the women forego their land ownership and inheritance rights to their male family members, especially the brothers, sons, and husbands. As a result, most women don't own agricultural land. Moreover, those who own land are unable to exercise the management decisions like crop choice, crop sale, or leasing or selling of land due to male influence. The dowry provided to women during their marriages is considered as the effective substitute for their land inheritance rights. In this scenario, reporting an innovative professional and successful female farmer in the study area is a black swam.

This doesn't, however, mean that there are no significant contributions of women in agriculture as a significant chunk of labour force in agriculture is provided by the feminine gender. In addition, the indoor agricultural operations like cleaning, storing, winnowing of agricultural produce besides small-scale livestock and poultry rearing are the women's specialization with no match. These agricultural activities are rewarding for females in terms of financial returns which are spent by the women on their personal and family needs.

Once again, the divide of socioeconomic status was conspicuous in the engagement of women in agricultural activities. Women from low socioeconomic status were more engaged in physical the laboor to execute agricultural operations in the fields. Conversely, the women from high socioeconomic status enjoyed a comparative leisured lifestyle with little or no burden of farming activities.

\section{Attitudes towards agricultural innovations and sugarcane productivity}

During FGDs, it was highlighted that the farming technologies have gradually changed with time, and with each passing day, new knowledge, technologies, and practices are innovated with desirous results in terms of agricultural production. However, all the agrarian innovations are associated with some uncertainties like social, economic, and technical risks involved in the adopting these technologies. The poor, illiterate, and smallholding farmers are at a high level of uncertainties related to agricultural technologies and are, therefore, more reluctant to adopt them. Comparably, the farmers from high socioeconomic status are better positioned to access and understand the innovative technologies, compare their relative advantages, try them on a small scale, discuss them with the experts, and be born the economic shocks in case of failure of these technologies.

Thus, literate farmers from high socioeconomic status and connected to communicative hubs are more likely to be innovative and develop a positive attitude towards agricultural innovations. Conversely, the low literate poor farmer with inadequate access to agrarian innovation-related knowledge it difficult to convince about innovative technologies resulting in their low agricultural production. It was further added that only a few of the common socioeconomic status farmers exhibited positive tendencies towards agricultural innovations. However, their economic constraints limited them in full-fledged adoption of these modern technologies.

\section{CONCLUSIONS}

The FGDs help to conclude that land disputes and land fragmentation under the tremendous pressure of population growth and urbanization are exerting high pressure on arable lands resulting in the shrinking of their area and reduce its productive capacity. The relatively high and immediate economic returns from alternate professions are additional sources of demoralization of farmers to continue an agricultural career. The social cohesion required for the farming profession established through the efforts of centuries is gradually weakening, as evident from reduced efforts of farmers in self-help-based activities at the village level and the mounting amount of unresolved local disputes. The government has intervened to supplement the agricultural production by the establishing of MFSCs in each district. However, the financial allocation to these centres and technical efficiencies of its employees is limited to meet the needs of all farmers. The women are the worst effect of a male-dominant agricultural profession as they are culturally deprived of their legal and human rights of land ownership and inheritance under the cover of patriarchal culture. Combining these factors is distressful for the farmers to develop a favoruable attitude towards modern technologies based agricultural innovations to enhance their agricultural production. The situation is specifically worse for farmers with low economic standings, smallholding, low literacy, and poor socioeconomic status.

\section{LIMITATION AND STUDY FORWARD}

This study only focused on some aspects of social factors responsible for sugarcane production. Further research can be made from other dimensions that are out of the scope of this research study. Similarly, this study is qualitative in nature, whereas other researchers may conduct quantitative studies to probe the extent of how these social factors influence sugarcane productivity. 


\section{ACKNOWLEDGEMENT}

The researchers fully acknowledged the support of FGDs participants whose participation made possible this study. Furthermore, the data is free from any sort of conflict of interest. Similarly, the authors completed the study on their own expenses, and no financial assistance for this research has been provided to them.

\section{AUTHORS' CONTRIBUTIONS}

Muhammad Nisar \& Asad Ullah: Designed and conducted the whole study, designed methodology, analysed the data, and wrote the paper.

Fazal Hanan: Assisted in FGDs and helped in summarizing of results.

Younas Khan: Data Collection, working on literature and after completing research, its review.

Habib Ur Rahman: Data Collection, writing references, and after completion of research review the article.

\section{REFERENCES}

1. Ahmad, S., Saleem, S., Zubair, Khalil, M.I.A., Sohil, K., \& Rehman, Z.U. (2012). Farmer' response and yield response of sugarcane in Jhang and Sargodha districts. Sarhad J. Agric. 28(2), 237-243.

2. Ahmed, V. \& Javed, A. (2016). National Study on Agriculture Investment in Pakistan. Working Paper \#157. A publication of the Sustainable Development Policy Institute (SDPI).

3. Ali, S., M. Ahmad, T. Ali, B. Shahbaz, G.A. Khan, M. Iftikhar \& F. Nosheen. (2013). Role of private sector in promoting IPM practices among farming community in Punjab, Pakistan. J. Anim. Plant Sci. 23, 1473-1476.

4. Angen, M. J. (2000). Evaluating interpretive inquiry: Reviewing the validity debate and opening the dialogue. Qualitative Health Research, 10, 378-395. https://doi.org/10.1177/104973230001000308

5. Aref, F., Gill, S.S. \& Aref, F. (2010). Tourism Development in Local Communities: As a Community Development Approach. Journal of American Sciences, 6(2), 155-162.

6. Ashour, M., Billings, L., Gilligan, D., Hoel, J. B., \& Karachiwalla, N. (2016). Do beliefs about agricultural inputs counterfeiting correspond with actual rates of counterfeiting? Evidence from Uganda. IFPRI Discussion Paper No. 1552. Washington, D.C.: International Food Policy Research Institute (IFPRI).

7. Bastiaensen, J. \& Marchetti, P. (2011). Rural Microfinance and Agricultural Value Chains: Strategies and Perspectives of the Fondo de Desarrollo Local in Nicaragua. World Scientific Book Chapters, in: Beatriz Armendáriz \& Marc Labie (ed.), The Handbook Of Microfinance, chapter 22, pages 461-500, World Scientific Publishing Co. Pte. Ltd.. https://doi.org/10.1142/9789814295666_0022

8. BenYishay A., \& Mobarak, A.M. (2013). Communicating with Farmers through Social Networks. Working Papers 1030, Economic Growth Center, Yale University.

9. BIF. (2018). Assessment of the Malting Barley Market System in Ethiopia (Report for UK Aid). United Kingdom: Business Innovation Facility publishing.

10. Birt, L., Suzanne, S., Debbie, C., Christine, C., \& Fiona, W. (2016). Member checking: A tool to enhance trustworthiness or merely a nod to validation? Qualitative Health Research, 26, 1802-1811. https://doi.org/10.1177/1049732316654870

11. Butt, T.M., Hassan, Z.Y., Mehmood, K., \& Muhammad, S. (2010). Role of Women in Agricultural Development and Their Constraints. Journal of Agriculture and Social Sciences, 6(3).

12. Carey, M. A., \& Smith, M. W. (1994). Capturing the group effect in focus groups: A special concern in analysis. Qualitative Health Research, 4, 123-127. https://doi.org/10.1177/104973239400400108

13. Charmaz, K. (2006). Constructing grounded theory: A practical guide through qualitative analysis. London, UK: Sage Publications Inc.

14. Cole, S. (2007). Tourism, culture and development: Hopes, dreams and realities in East Indonesia. Clevedon, UK: Channel view publications. https://doi.org/10.21832/9781845410711

15. Deng, X., Huang, J., Rozelle, S., Zhang, J., \& Li, Z. (2015). Impact of urbanization on cultivated land changes in China. Land Use Policy, 45, 1-7. https://doi.org/10.1016/j.landusepol.2015.01.007

16. Doyle, S. (2007). Member checking with older women: A framework for negotiating meaning. Health Care for Women International, 28, 888-908. https://doi.org/10.1080/07399330701615325

17. Eklund, L., \& Thompson, D. (2015). Differences in resource management affects drought vulnerability across the borders between Iraq Syria and Turkey Ecol. Soc. Submitted.

18. FAO. (2016). Food and Agriculture Organization.

19. Francis, Z. N., Dinye, R. D. \& Kasanga, R. K. (2013). Urbanization and its Impact on Agricultural Lands in Growing Cities in Developing Countries: A Case Study of Tamale in Ghana. Modern Social Science Journal, 2(2), 256-287.

20. Gabre-Madhin, Z. \& Haggblade, S. (2001). Success in African Agriculture: Results of an Expert Survey. International Food Policy Research Institute. Washington DC.

21. Glaser, B.G. (1978). Theoretical Sensitivity. Mill Valley, CA, USA: Sociology Press.

22. GOKP. (2018). Government of Khyber Pakhtunkhwa

23. GOP. (2018). Ministry of Finance Division, Economic Advisor's Wing, Islamabad, Pakistan. 
24. Habib, N., Rani, S., Siddiqui, S., Zaman, S. \& Anwar, M. Z. (2014). Impact of MAJOR Farm Inputs on Productivity of Sugarcane: A Case Study in Tehsil KOT Addu, Punjab, Pakistan. Pakistan J. Agric. Res. 27(4), 325-330.

25. Hassan, M. (2000). Role of Agha Khan Rural Support Program (AKRSP) in dissemination of new agriculture technologies in Gilgit. M.Sc (H) Thesis, Department of Agricultural Extention education and communication, NWFP Agricultural University, Peshawar, Pakistan.

26. Iheke, O. R. (2009). Effects of Sustainable Land Management Practices on Agricultural Production: The Case of Arable Crop Farmers in Abia State, Nigeria. Internal Journal of Agriculture and Rural Development, 11(2), $39-44$.

27. Kasenge, V. (1998). Socio-economic factors influencing the level of Soil Management Practices on Fragile Land. In Proceedings of the 16th Conference of Soil Science Society of East Africa (Eds.: ShayoNgowi, A.J., G. Ley and F.B.R Rwehumbiza), 13th-19th, December 1998, Tanga, Tanzania pp.102- 112.

28. Khan, M. \& Deshmukh, I. (2015). Sugar Sector. Journal of Management and Social Sciences.

29. Khan, M., Sajjad, M., Hameed, B., Khan, M.N., \& Jan, A. (2012). Participation of Women in Agriculture Activities in District Peshawar. Sarhad Journal of Agriculture, 28(1).

30. Khan, M.Z., Javidullah, Ahmad, S., \& Qasim, M. (2012). Assessing Professional Capabilities of Agriculture Officers for Weed Control: A Case Study of Khyber Pakhtunkhwa-Pakistan. Pakistan Journal of Weed Science, 18, 79-90.

31. Leech, N. L., \& Onwuegbuzie, A. J. (2007). An array of qualitative data analysis tools: A call for data analysis triangulation. School Psychology Quarterly, 22, 557-584. https://doi.org/10.1037/1045-3830.22.4.557

32. Malik, R., \& Ali, M. (2015). The Impact of Urbanization on Agriculture Sector: A Case Study of Peshawar, Pakistan. Journal of Resources Development and Management, (8), 79-85.

33. Mignouna, B., Manyong, M., Rusike, J., Mutabazi, S., \& Senkondo, M. (2011). Determinants of Adopting Imazapyr-Resistant Maize Technology and its Impact on Household Income in Western Kenya: AgBioforum, 14(3), 158-163.

34. Hall, B. and Khan, B. (2002). Adoption of new technology. New Economy Handbook. https://doi.org/10.3386/ w9730

35. Morgan, D.L. (1988). Focus group as qualitative research. Newbury Park, CA: Sage Publications Inc.

36. Morgan, D.L. (1995). Why things (sometimes) go wrong in focus groups. Qualitative Health Research, 5, 516523. https://doi.org/10.1177/104973239500500411

37. Muawanah, U. (2018). Does Land Conflict Matter to Farm Productivity? A Case Study of Cambodia, The Ministry of Marine Affairs and Fisheries Jakarta, Indonesia. Asian Journal of Agriculture and Development, 15(2), 77-92.

38. Mughal, M. A. Z. (2019). Rural urbanization, land, and agriculture in Pakistan. ASIAN Geographer, 36 (1), 8191. https://doi.org/10.1080/10225706.2018.1476255

39. Muyanga, M. \& Gitau, R. (2013). Do Land Disputes Affect Smallholder Agricultural Productivity? Evidence from Kenya. Journal of Economics and Sustainable Development, 4(14), 112-121.

40. Nazir, A., Jariko, G. A. \& Junejo, M. A. (2013). Factors Affecting Sugarcane Production in Pakistan. Pakistan Journal of Commerce and Social Sciences, 7 (1), 128-140.

41. Okezie, C., Ulunma, A.C. \& Sulaiman, J. (2012). Exploring the Link between Land Fragmentation and Agricultural Productivity. International Journal of Agriculture and Forestry, 2(1), 30-34. https://doi.org/10 $.5923 /$ j.ijaf.20120201.05

42. Pakistan Bureau of Statistics .(2008).

43. Pakistan Bureau of Statistics. (2017).

44. Pakistan Sugar Mills Association (PSMA). (2019).

45. Perviaz. U., F. Khan, D. Jan, Z. Huma \& M. Zafarullah. (2013). An Analysis of Sugarcane Production With Reference to Extension Services in Union Council Malakandher-Peshawar. SJA, 29(1), 37-42.

46. RDI. (2007). Women \& Land - An Avenue to Poverty Alleviation. International Women's Day Breakfast Forum.

47. Reza, S. M., Riazi, M. H. \& Khan, M. M. H. (2016). Productivity and Profitability of Sugarcane Production in Northern Bangladesh. Indian Journal of Commerce \& Management Studies, VII (1), Available from:

48. Saadi, H., Madhei, K.N. \& Movahedi, R. (2008). Surveying on the Wheat Farmers Access and Confidence to Information and Communication Channels (ICCs) about Controlling Eurygaster integriceps in Hamedan Province, Iran. American Journal of Agricultural and Biological Sciences, 3, 497-501. https://doi.org/10.38 44/ajabssp.2008.497.501

49. Samiullah, M.A. Khan and A. Rehman. (2018). Spatial and temporal analysis of landholdings and farm fragmentation in Peshawar city district, Pakistan. Sarhad Journal of Agriculture, 34(3), 550-562. https://doi.org/10.17582/journal.sja/2018/34.3.550.562

50. Sharif Uddin, A.B.M., Rahman, M.M., Alam, M.B., \& Kamaly, M.H.K. (2014). Factors contribution to the adoption of production technologies by potato growers in northwest bangladesh. J. Agribus. Rural Dev. 3, 283297. 
51. Singh, A., K. \& S. Narian. (2008). Effectiveness of public and private extension system in delivering services. Indian Research Journal of Extension Education, 8, 2-3.

52. Song, W. and B. C. Pijanowski. (2014). The effects of China's cultivated land balance program on potential land productivity at a national scale. Applied Geography, 46, 158-170. https://doi.org/10.1016/j apgeog.2013.11.009

53. Strauss, A.L. (1987). Qualitative Analysis for Social Scientists. Cambridge, UK: Cambridge University Press. https://doi.org/10.1017/CBO9780511557842

54. Tefera, D. A., Bijman, J. \& Slingerland, M. (2016). Smallholder integration into modern agrifood value chains: A case study of the Ethiopian malt barley industry (IBM Working paper 2016-01). Wageningen, The Netherlands: Wageningen University and Research.

55. Uaiene, R., Arndt, C., \& Masters, W. (2009). Determinants of Agricultural Technology Adoption in Mozambique. Discussion papers No. 67E.

56. Ullah, R., Khan, Z,M., Ullah, K. \& Butt, T. M. (2010). Model Farm Services Center Approach: An Implication to Boost Farmer's Yield. Agricultural Sciences, 6, 953-960. https://doi.org/10.4236/as.2015.69092

57. WB \& DRC (The World Bank and the Development Research Center of the State Council, P. R. China). (2014). Urban China: Toward Efficient, Inclusive, and Sustainable Urbanization. Washington DC.

58. Zaidi, S.M.R., A. Saeed \& S.M. Shahid. (2013). Impact of low-sugar-cane-yield on sugar industry of Pakistan. Interdisciplin. J. Cont. Res. Bus. 4(12), 58-86. 